\title{
Energy utilisation of broiler chickens in response to guanidinoacetic acid supplementation in diets with various energy contents
}

\author{
Sayed Sadra Ale Saheb Fosoul ${ }^{1}$, Arash Azarfar $^{1 *}$, Abbasali Gheisari ${ }^{2}$ and Heshmatollah Khosravinia ${ }^{1}$ \\ ${ }^{1}$ Department of Animal Sciences, Agriculture Faculty, Lorestan University, PO Box 465, Khoramabad, Lorestan, Iran \\ ${ }^{2}$ Animal Science Research Department, Isfahan Agricultural and Natural Resources Research and Education Center, AREEO, \\ PO Box 199-81785, Isfahan, Iran
}

(Submitted 12 October 2017 - Final revision received 3 December 2017 - Accepted 6 December 2017 - First published online 25 April 2018)

\section{Abstract}

This experiment was conducted to investigate the effects of guanidinoacetic acid (GAA) on productive performance, intestinal morphometric features, blood parameters and energy utilisation in broiler chickens. A total of 390 male broiler chicks (Ross 308) were assigned to six dietary treatments based on a factorial arrangement $(2 \times 3)$ across $1-15$ and $15-35$-d periods. Experimental treatments consisted of two basal diets with standard (STD; starter: $12.56 \mathrm{MJ} / \mathrm{kg}$ and grower: $12.97 \mathrm{MJ} / \mathrm{kg}$ ) and reduction (LME; starter: $11.93 \mathrm{MJ} / \mathrm{kg}$ and grower: $12.33 \mathrm{MJ} / \mathrm{kg}$ ) of apparent metabolisable energy (AME) requirement of broiler chickens each supplemented with $0,0 \cdot 6$ and $1 \cdot 2 \mathrm{~g} / \mathrm{kg}$ GAA. Supplemental $1 \cdot 2 \mathrm{~g} / \mathrm{kg}$ GAA decreased the negative effects of feed energy reduction on weight gain across starter, growing and the entire production phases $(P<0 \cdot 05)$. Energy retention as fat and total energy retention were increased when birds received LME diets supplemented with $1.2 \mathrm{~g} / \mathrm{kg}$ GAA $(P<0 \cdot 05)$. Net energy for production $\left(\mathrm{NE}_{\mathrm{p}}\right)$ and total heat production increased in birds fed LME diets containing $1 \cdot 2 \mathrm{~g} / \mathrm{kg}$ GAA $(P<0 \cdot 05)$. A significant correlation was observed between dietary $\mathrm{NE}_{\mathrm{p}}$ and weight gain of broilers $(r 0.493 ; P=0.0055)$, whereas this relationship was not seen with AME. Jejunal villus height and crypt depth were lower in birds fed LME diets $(P<0 \cdot 05)$. Serum concentration of creatinine increased in broilers fed LME diets either supplemented with $1.2 \mathrm{~g} / \mathrm{kg}$ GAA or without GAA supplementation $(P<0.05)$. Supplemental GAA improved performance of chickens fed LME diet possibly through enhanced dietary $\mathrm{NE}_{\mathrm{p}}$. The $\mathrm{NE}_{\mathrm{p}}$ could be preferred over the AME to assess response of broiler chickens to dietary GAA supplementation.

\section{Key words: Broiler chickens: Guanidinoacetic acid: Energy retention: Net energy: Intestinal morphology}

Energy is a component of poultry diets, representing about half of the expenses that producers have to pay for broilers' feed ${ }^{(1)}$. At the same time, a part of this energy is wasted in the body by heat increment produced during the utilisation of different chemical components ${ }^{(2)}$. As such, nutritionists are always looking for novel approaches to improve availability of energy for broiler chickens. One mechanism to store the flow of energy in the body within the cells is mediated through the formation of high-energy phosphate bonds ${ }^{(3)}$. However, impaired bioenergetics is accompanied by low levels of creatine - a compound that plays a key role in the formation of phosphate-bound cellular energy ${ }^{(4)}$. Poultry are uricotelic animals, lacking enzymes to synthesise enough arginine de novo as a precursor for creatine ${ }^{(5)}$. In addition, in average, $1.7 \%$ of the total body creatine and phosphocreatine pool is irreversibly converted to creatinine and excreted in the urine, daily ${ }^{(6)}$. Therefore, creatine replenishment from an exogenous source is necessary, particularly in younger than in adult animals ${ }^{(7)}$. However, nowadays, diets of broilers are free of animal by-products, which reduces the chance of animals to obtain exogenous creatine from an all-vegetable feed ${ }^{(8)}$.

Guanidinoacetic acid (GAA) is a readily available precursor for creatine, synthetised in the kidney from glycine and L-arginine by L-arginine:glycine amidinotransferase. In the second reaction, GAA forms creatine in the liver via the action of guanidinoacetate $N$-methyltransferase. The feed-grade GAA is provided commercially and has a better potential to be included in practical broilers' diets because it is more stable and cost-efficient than creatine ${ }^{(9)}$. Supplementation of dietary GAA was shown to have sparing effects for arginine, which increase arginine availability in broiler chickens ${ }^{(9)}$. In addition, arginine has influenced the intestinal morphometric features ${ }^{(10)}$; therefore, it may possible that dietary inclusion of GAA affects the

Abbreviations: AIA, acid-insoluble ash; AME, apparent metabolisable energy; CFr, total carcass fat retention; DWG, daily weight gain; FCR, feed conversion ratio; GAA, guanidinoacetic acid; GE, gross energy; $\mathrm{HP}_{\mathrm{t}}$, total heat production; $\mathrm{HP}_{\mathrm{f}}$, heat production per kg of feed intake; LME, basal diet with energy reduction below the level recommended by Ross 308 (2014) broiler manual (starter: $11.93 \mathrm{MJ} / \mathrm{kg}$ and grower: $12 \cdot 33 \mathrm{MJ} / \mathrm{kg}$ ); NE , net energy for production; $\mathrm{RE}_{\mathrm{c}}$, energy retained in the carcass; $\mathrm{RE}_{\mathrm{f}}$, carcass gross energy retained as carcass fat; $\mathrm{RE}_{\mathrm{p}}$, carcass gross energy retained as carcass protein; STD, basal diet with energy level recommended by Ross 308 (2014) broiler manual (starter: $12.56 \mathrm{MJ} / \mathrm{kg}$ and grower: $12.97 \mathrm{MJ} / \mathrm{kg}$ ); TP, total protein; UA, uric acid. 
intestinal digestibility and absorption of nutrients. In the recent works, GAA was found to be more efficient than dietary creatine for improving the muscular creatine stores in human ${ }^{(11)}$ and Yucatan miniature pigs ${ }^{(12)}$. Moreover, GAA enhances the ratio of muscular creatine and phosphocreatine to ATP in broiler chickens ${ }^{(3,13)}$. In addition, supplemental GAA had beneficial effects on growth performance of broilers ${ }^{(14)}$ and turkey ${ }^{(15)}$, whereas the same effects were not observed in the other trials $^{(13,16,17)}$. The impact of GAA on daily feed intake (DFI) of broilers is equivocal ${ }^{(13,18,19)}$; however, we expected that GAA inclusion in diets with lower energy content may improve overall body energy retention as fat $\left(\mathrm{RE}_{\mathrm{f}}\right)$ or protein $\left(\mathrm{RE}_{\mathrm{p}}\right)$, thereby contributing to a better understanding of energy utilisation in broiler chickens. Most researches investigating the effects of GAA have focused on growth performance or concentration of muscular energetic metabolites in broilers receiving diets containing various levels of apparent metabolisable energy (AME) contents, and less attention has been payed to effect of supplemental GAA on dietary net energy for production $\left(\mathrm{NE}_{\mathrm{p}}\right)$.

We hypothesised that supplementation of GAA in diets with different energy contents may influence energy utilisation, intestinal morphology and consequently growth performance of broiler chickens. Furthermore, we hypothesised that dietary inclusion of GAA could affect $\mathrm{NE}_{\mathrm{p}}$ in broiler chickens. Therefore, the current study was conducted to evaluate effects of GAA $(0,0.6$ and $1.2 \mathrm{~g} / \mathrm{kg})$ and energy content of the diet (with or without energy reduction) on production performance, gut morphology, blood parameters and energy utilisation of broiler chickens using comparative slaughter technique.

\section{Methods}

All experimental procedures were evaluated and approved by the Institutional Animal Care and Ethics Committee of the Lorestan University.

\section{Animals, diets and experiment design}

Male broiler chickens (Ross 308), 390 d old, were purchased from a commercial hatchery and used in this experiment. Upon arrival, chicks were weighed, wing-banded and randomly assigned to the treatment groups so that the initial weights were similar among different treatment groups. Five replicate cages of thirteen chicks each were randomly allotted to six dietary treatments based on a factorial arrangement of treatments $(2 \times 3)$ in a completely randomised design across starter (1-15d) and growing (15-35d) periods. Experimental treatments included two basal diets with standard (STD; starter: $12.56 \mathrm{MJ} / \mathrm{kg}$ and grower: $12.97 \mathrm{MJ} / \mathrm{kg}$ ) or reduction (LME; starter: $11.93 \mathrm{MJ} / \mathrm{kg}$ and grower: $12 \cdot 33 \mathrm{MJ} / \mathrm{kg}$ ) of $\mathrm{AME}$ requirement of broiler chickens (Ross 308) each supplemented with $0,0.6$ and $1.2 \mathrm{~g} / \mathrm{kg}$ GAA (CreAMINO ${ }^{\circledR}$; Evonik Degussa Gmbh) by replacing with an equal quantity of maize and soyabean meal. Diets were formulated to be iso-energetic and iso-nitrogenous and to meet or marginally exceed nutrient requirements provided by Ross manual (Aviagen ${ }^{(20)}$; Tables 1 and 2) across different periods.
Birds had free access to feed and water throughout the experiment. All experimental diets were fed in mash form. The birds were reared in a power-ventilated broiler house equipped with battery cages (length $124 \mathrm{~cm} \times$ width $65 \mathrm{~cm}$ ). Birds' density was $7.7 \mathrm{~kg} / \mathrm{m}^{2}$ during days $1-15$ of age and $23.4 \mathrm{~kg} / \mathrm{m}^{2}$ during days 15-35 of age. The lighting programme consisted of $23 \mathrm{~h} \mathrm{light}$ and $1 \mathrm{~h}$ darkness. The light was provided by incandescent bulbs, and the light intensity at bird level was 30 lux. Ambient temperature was kept at $31^{\circ} \mathrm{C}$ for days $1-3$ and gradually decreased thereafter to $24^{\circ} \mathrm{C}$ by the end of the $3 \mathrm{rd}$ week. Relative humidity was maintained between 50 and $70 \%$.

\section{Data collection and sampling}

Feed intake and live body weight (BW) of chickens in each cage were recorded individually from 1 to $35 \mathrm{~d}$, and DFI, daily weight gain (DWG) and feed conversion ratio (FCR; feed intake/weight gain) were calculated accordingly. On days 15 and 35 of the experiment, two birds close to the mean BW of cage were individually weighed and slaughtered. Carcass, breast, leg, abdominal fat and liver were collected, weighed and expressed as a percentage of BW.

At the beginning of the experiment (day 1 ), thirty randomly selected birds were killed by cervical dislocation and stored at $-20^{\circ} \mathrm{C}$ pending carcass analyses. At day 8 post hatch, two birds from each cage (those with the closest BW to the cage average) were selected, weighed and transferred to one of thirty metabolic cages (length $60 \times$ width $30 \times$ height $30 \mathrm{~cm}$ ) located in a temperature-controlled room with the ambient temperature of $24^{\circ} \mathrm{C}$ and relative humidity of $60 \%$. The average area, equivalent to that occupied by these two chicks in our main cages, was calculated and restricted by wire mesh for the remaining chicks in order to keep the stocking density of $7.7 \mathrm{~kg} / \mathrm{m}^{2}$ per cage until day 15 of experiment. In metabolic cages, all birds had free access to the experimental diets for preliminary 4-d adaptation period followed by $3 \mathrm{~d}$ of excretion collection in triplicate. A source of acid-insoluble ash (AIA; Celite*545; Merck KGaA) was added to all diets $(10 \mathrm{~g} / \mathrm{kg})$ as an indigestible marker to measure the AME of experimental diets during this period. Excreta were collected using trays located beneath each cage to determine AME. Contamination in excreta (e.g. feathers and skin debris) was carefully removed and the collected excreta per cage during the collection period were pooled and stored at $-20{ }^{\circ} \mathrm{C}$. Before analysis, samples of excreta were thawed and dried at $60^{\circ} \mathrm{C}$ for $48 \mathrm{~h}$ in a forced air oven, ground to pass through a $0.5-\mathrm{mm}$ sieve and stored in airtight plastic containers. After collection period, all birds were weighed, euthanised by cervical dislocation and immediately frozen. A comparative slaughter technique was applied to determine retention of nutrients. In brief, the whole carcass of frozen birds (feathers, head, feet and all organs) was minced twice, and thoroughly mixed in a blender to obtain a homogeneous sample of approximately $200 \mathrm{~g}$. The samples were freeze-dried and two sub-samples from each replicate were mixed after drying and ground together. Hence, chemical analyses were performed on one sample per cage. The same procedure was applied to the carcass of thirty birds taken at the initiation of the experiment. The data were used to determine the DM, carcass 
Table 1. Dietary composition and nutrients during starter period

\begin{tabular}{|c|c|c|c|c|c|c|}
\hline \multirow[b]{3}{*}{ Items } & \multicolumn{6}{|c|}{ Experimental diet } \\
\hline & \multicolumn{3}{|c|}{ LME } & \multicolumn{3}{|c|}{ STD } \\
\hline & GAAO & GAA0.6 & GAA1.2 & GAA0 & GAA0.6 & GAA1.2 \\
\hline \multicolumn{7}{|l|}{ Ingredients (g/kg) } \\
\hline Maize (77 g/kg crude protein) & $544 \cdot 5$ & $548 \cdot 4$ & $552 \cdot 1$ & $514 \cdot 8$ & $518 \cdot 4$ & $522 \cdot 7$ \\
\hline SBM (450 g/kg crude protein) & 374 & 370 & 366 & 379 & 375 & 371 \\
\hline MGM (606 g/kg crude protein) & 27 & 27 & 27 & 27 & 27 & 27 \\
\hline Soyabean oil & $11 \cdot 6$ & 11 & $10 \cdot 5$ & $36 \cdot 5$ & 36 & 35 \\
\hline Monocalcium phosphate & $11 \cdot 8$ & $11 \cdot 8$ & $11 \cdot 8$ & $11 \cdot 8$ & $11 \cdot 8$ & $11 \cdot 8$ \\
\hline Calcium carbonate & $15 \cdot 7$ & $15 \cdot 7$ & $15 \cdot 7$ & $15 \cdot 7$ & $15 \cdot 7$ & $15 \cdot 7$ \\
\hline DL-Met & $3 \cdot 8$ & $3 \cdot 8$ & 3.9 & $3 \cdot 8$ & 3.9 & 3.9 \\
\hline L-Lysine $\mathrm{HCl}$ & 3.9 & 4 & $4 \cdot 1$ & $3 \cdot 8$ & 3.9 & 4 \\
\hline L-Thr & $1 \cdot 2$ & $1 \cdot 2$ & $1 \cdot 2$ & $1 \cdot 1$ & $1 \cdot 2$ & $1 \cdot 2$ \\
\hline Choline & 1 & 1 & 1 & 1 & 1 & 1 \\
\hline GAA & 0 & 0.6 & $1 \cdot 2$ & 0 & 0.6 & $1 \cdot 2$ \\
\hline Vitamin and mineral premix ${ }^{*}$ & 2 & 2 & 2 & 2 & 2 & 2 \\
\hline Sodium chloride & 3.5 & 3.5 & 3.5 & 3.5 & 3.5 & 3.5 \\
\hline \multicolumn{7}{|l|}{ Calculated nutrient level (as-fed basis) } \\
\hline $\mathrm{ME}(\mathrm{MJ} / \mathrm{kg})$ & 11.93 & 11.93 & 11.93 & 12.56 & $12 \cdot 56$ & 12.56 \\
\hline Crude protein (g/kg) & 230 & 230 & 230 & 230 & 230 & 230 \\
\hline Lys $(\mathrm{g} / \mathrm{kg})$ & $14 \cdot 3$ & $14 \cdot 3$ & $14 \cdot 3$ & $14 \cdot 3$ & $14 \cdot 3$ & $14 \cdot 3$ \\
\hline Met + Cys (g/kg) & $10 \cdot 7$ & $10 \cdot 7$ & $10 \cdot 7$ & $10 \cdot 7$ & $10 \cdot 7$ & $10 \cdot 7$ \\
\hline $\operatorname{Thr}(\mathrm{g} / \mathrm{kg})$ & $9 \cdot 7$ & $9 \cdot 7$ & $9 \cdot 7$ & $9 \cdot 7$ & 9.7 & $9 \cdot 7$ \\
\hline $\operatorname{Arg}(\mathrm{g} / \mathrm{kg})$ & $14 \cdot 2$ & 14.9 & $14 \cdot 6$ & $14 \cdot 5$ & 14.9 & $14 \cdot 2$ \\
\hline $\mathrm{Ca}(\mathrm{g} / \mathrm{kg})$ & $9 \cdot 6$ & $9 \cdot 6$ & $9 \cdot 6$ & $9 \cdot 6$ & $9 \cdot 6$ & $9 \cdot 6$ \\
\hline Available P $(\mathrm{g} / \mathrm{kg})$ & $4 \cdot 8$ & 4.8 & $4 \cdot 8$ & $4 \cdot 8$ & 4.8 & $4 \cdot 8$ \\
\hline Dietary cation-anion balance (meq/kg) & $213 \cdot 7$ & $211 \cdot 3$ & $216 \cdot 1$ & $216 \cdot 9$ & $212 \cdot 0$ & $214 \cdot 4$ \\
\hline \multicolumn{7}{|l|}{ Analysed values (as-fed basis) } \\
\hline Crude protein $(\mathrm{g} / \mathrm{kg})$ & $222 \cdot 7$ & $213 \cdot 6$ & $225 \cdot 6$ & $215 \cdot 8$ & $213 \cdot 8$ & $227 \cdot 7$ \\
\hline $\mathrm{Ca}(\mathrm{g} / \mathrm{kg})$ & 9.58 & $9 \cdot 63$ & 9.63 & $9 \cdot 70$ & 9.65 & 9.72 \\
\hline Total P $(\mathrm{g} / \mathrm{kg})$ & $5 \cdot 66$ & 5.99 & $5 \cdot 94$ & $6 \cdot 26$ & 6.07 & $6 \cdot 36$ \\
\hline Met $(\mathrm{g} / \mathrm{kg})$ & $7 \cdot 20$ & $7 \cdot 22$ & $7 \cdot 22$ & $7 \cdot 24$ & $7 \cdot 22$ & $7 \cdot 25$ \\
\hline Cys $(g / k g)$ & 3.71 & 3.72 & 3.72 & 3.75 & 3.73 & 3.76 \\
\hline Met + Cys (g/kg) & $10 \cdot 5$ & $10 \cdot 6$ & $10 \cdot 6$ & $10 \cdot 9$ & $10 \cdot 7$ & 11 \\
\hline Lys $(\mathrm{g} / \mathrm{kg})$ & $14 \cdot 3$ & 14.4 & 14.4 & $14 \cdot 7$ & 14.5 & $14 \cdot 8$ \\
\hline Thr (g/kg) & 9.5 & $9 \cdot 6$ & $9 \cdot 6$ & 9.9 & $9 \cdot 7$ & $10 \cdot 0$ \\
\hline $\operatorname{Arg}(\mathrm{g} / \mathrm{kg})$ & $14 \cdot 7$ & $14 \cdot 8$ & $14 \cdot 8$ & $15 \cdot 1$ & 14.9 & $15 \cdot 2$ \\
\hline
\end{tabular}

LME, basal diet with energy reduction below the level recommended by Ross 308 (2014) broiler manual (starter: $11.93 \mathrm{MJ} / \mathrm{kg}$ and grower: $12.33 \mathrm{MJ} / \mathrm{kg}$ ); STD, basal diet with energy level recommended by Ross 308 (2014) broiler manual (starter: $12.56 \mathrm{MJ} / \mathrm{kg}$ and grower: $12.97 \mathrm{MJ} / \mathrm{kg}$ ); GAA0, basal diet; GAA0.6, basal diet supplemented with 0.6 g/kg guanidinoacetic acid; GAA1.2, basal diet supplemented with $1.2 \mathrm{~g} / \mathrm{kg}$ guanidinoacetic acid; SBM, soyabean meal; MGM, maize gluten meal; GAA, guanidinoacetic acid.

* Vitamin premix provided per $\mathrm{kg}$ of diet: vitamin A (retinol), $3600 \mu \mathrm{g}$; vitamin $\mathrm{D}_{3}$ (cholecalciferol), $125 \mu \mathrm{g}$; vitamin $\mathrm{E}$ (tocopheryl acetate), $63 \mathrm{mg}$; vitamin $\mathrm{K}_{3}, 3.5 \mathrm{mg}$; thiamine, $3 \mathrm{mg}$; riboflavin, $7.5 \mathrm{mg}$; pantothenic acid, $18 \mathrm{mg}$; pyridoxine, $4.3 \mathrm{mg}$; cyanocobalamin, $0.017 \mathrm{mg}$; niacin, $65 \mathrm{mg}$; biotin, $0.3 \mathrm{mg}$; folic acid, $2 \mathrm{mg}$; choline chloride, $600 \mathrm{mg}$; antioxidant $100 \mathrm{mg}$; mineral premix provided per kg of diet: $\mathrm{Fe}\left(\mathrm{FeSO}_{4} \cdot 7 \mathrm{H}_{2} \mathrm{O}, 20.09 \% \mathrm{Fe}\right), 80 \mathrm{mg} ; \mathrm{Mn}\left(\mathrm{MnSO}_{4} \cdot \mathrm{H}_{2} \mathrm{O}, 32.49 \% \mathrm{Mn}\right), 120 \mathrm{mg} ; \mathrm{Zn}(\mathrm{ZnO}, 80 \cdot 35 \% \mathrm{Zn}), 110 \mathrm{mg} ; \mathrm{Cu}\left(\mathrm{CuSO} .5 \mathrm{H}_{2} \mathrm{O}\right)$, $16 \mathrm{mg}$; iodine ( $\mathrm{KI}, 58 \% \mathrm{I}), 1.3 \mathrm{mg}$; Se $\left(\mathrm{NaSeO}_{3}, 45.56 \% \mathrm{Se}\right), 0.3 \mathrm{mg}$.

$\mathrm{RE}_{\mathrm{f}}$ and $\mathrm{RE}_{\mathrm{p}}$ in broiler chickens during days $1-15$ of the experimental period.

\section{Morphology of small intestine}

Two birds from each cage were slaughtered on day 15, and segments of their small intestine were sampled from the midpoint of the duodenum (intestine from the gizzard to pancreatic and bile ducts) and jejunum (midway between the point of entry of the bile ducts and Meckel's diverticulum). The intestinal samples were evaluated for the villus height, crypt depth, villus height:crypt depth ratio, villus width and villus surface area. Segments with $1 \cdot 5-\mathrm{cm}$ length were gently flushed twice with physiological saline solution $(1 \% \mathrm{NaCl})$ to remove intestinal contents and placed in $10 \%$ formalin in $0.1 \mathrm{~m}$ phosphate buffer $(\mathrm{pH}=7 \cdot 0)$ for fixation. The samples were processed for $24 \mathrm{~h}$ in a tissue processor with ethanol as dehydrant and were embedded in paraffin. Sections $(5 \mu \mathrm{m})$ were made and stained with haematoxylin-eosin. An optical microscope (Olympus CX31) was used for morphological examination of small intestine samples. A total of ten intact, well-oriented villus-crypt units were selected for each intestinal cross section (three crosssections/sample and thirty-six cross-sections/treatment, for a total of 360 measurements/treatment). Villus height $(\mu \mathrm{m})$ was measured from the tip of the villus to the villus crypt junction, and crypt depth was defined as the depth of the invagination between two villi. Villus height:crypt depth ratio (V:C) was then calculated. Villus width was measured at the middle point of the villus. The formula for calculating villus surface area was $2 \pi \times$ (villus width/2) $\times$ villus height. The average of values for each cross section was used for data analysis.

\section{Blood parameters}

At $35 \mathrm{~d}$ of age, two birds from each pen were randomly selected for blood sampling via a wing vein. The serum was harvested 
Table 2. Dietary composition and nutrients during growing period

\begin{tabular}{|c|c|c|c|c|c|c|}
\hline \multirow[b]{3}{*}{ Items } & \multicolumn{6}{|c|}{ Experimental diet } \\
\hline & \multicolumn{3}{|c|}{ LME } & \multicolumn{3}{|c|}{ STD } \\
\hline & GAAO & GAA0.6 & GAA1.2 & GAAO & GAA0.6 & GAA1 2 \\
\hline \multicolumn{7}{|l|}{ Ingredients $(\mathrm{g} / \mathrm{kg})$} \\
\hline Maize ( $77 \mathrm{~g} / \mathrm{kg}$ crude protein) & 567 & 570 & 574 & 535 & 539 & 542.6 \\
\hline SBM (450 g/kg crude protein) & 370 & 366.5 & 363 & 376 & 372 & 368 \\
\hline Soyabean oil & $25 \cdot 5$ & 25 & 24 & $51 \cdot 1$ & 50.5 & 50 \\
\hline Monocalcium phosphate & 10 & 10 & 10 & 10 & 10 & 10 \\
\hline Calcium carbonate & 14 & $14 \cdot 2$ & 14 & 14.5 & $14 \cdot 4$ & $14 \cdot 3$ \\
\hline DL-Met & 3.5 & 3.5 & 3.5 & 3.5 & 3.5 & 3.6 \\
\hline L-Lysine $\mathrm{HCl}$ & $2 \cdot 3$ & $2 \cdot 4$ & 2.5 & $2 \cdot 2$ & $2 \cdot 3$ & 2.4 \\
\hline L-Thr & 0.75 & 0.8 & 0.8 & 0.75 & 0.8 & 0.85 \\
\hline Choline & 1.25 & 1.25 & 1.25 & 1.25 & 1.25 & 1.25 \\
\hline GAA & 0 & 0.6 & 1.2 & 0 & 0.6 & 1.2 \\
\hline Vitamin and mineral premix ${ }^{*}$ & 2 & 2 & 2 & 2 & 2 & 2 \\
\hline Sodium chloride & 3.7 & $3 \cdot 6$ & $3 \cdot 4$ & 3.7 & 3.6 & 3.5 \\
\hline $\mathrm{NaHCO}_{3}$ & 0 & 0.15 & 0.35 & 0 & 0.07 & 0.3 \\
\hline \multicolumn{7}{|l|}{ Calculated nutrient level (as-fed basis) } \\
\hline $\mathrm{ME}(\mathrm{MJ} / \mathrm{kg})$ & 12.33 & $12 \cdot 33$ & $12 \cdot 33$ & 12.97 & 12.97 & $12 \cdot 97$ \\
\hline Crude protein $(\mathrm{g} / \mathrm{kg})$ & 215 & 215 & 215 & 215 & 215 & 215 \\
\hline Lys $(\mathrm{g} / \mathrm{kg})$ & 12.9 & 12.9 & $12 \cdot 9$ & 12.9 & 12.9 & 12.9 \\
\hline Met + Cys $(\mathrm{g} / \mathrm{kg})$ & 9.9 & 9.9 & 9.9 & 9.9 & 9.9 & 9.9 \\
\hline $\operatorname{Thr}(\mathrm{g} / \mathrm{kg})$ & 8.8 & $8 \cdot 8$ & $8 \cdot 8$ & $8 \cdot 8$ & $8 \cdot 8$ & 8.8 \\
\hline $\operatorname{Arg}(\mathrm{g} / \mathrm{kg})$ & 13.7 & $14 \cdot 1$ & 14.5 & $14 \cdot 0$ & 14.4 & 13.7 \\
\hline $\mathrm{Ca}(\mathrm{g} / \mathrm{kg})$ & 8.7 & 8.7 & 8.7 & 8.7 & 8.7 & 8.7 \\
\hline Available P (g/kg) & $4 \cdot 34$ & 4.34 & 4.34 & $4 \cdot 3$ & $4 \cdot 3$ & $4 \cdot 3$ \\
\hline Dietary cation-anion balance (meq/kg) & $220 \cdot 87$ & 220 & 220 & $221 \cdot 61$ & 220 & 220 \\
\hline \multicolumn{7}{|l|}{ Analysed values (as-fed basis) } \\
\hline Crude protein $(\mathrm{g} / \mathrm{kg})$ & $197 \cdot 3$ & $200 \cdot 3$ & $196 \cdot 7$ & 203.0 & 197.5 & $201 \cdot 0$ \\
\hline $\mathrm{Ca}(\mathrm{g} / \mathrm{kg})$ & 8.72 & 8.92 & 8.78 & 9.04 & 8.80 & 8.91 \\
\hline Total P (g/kg) & 5.48 & $5 \cdot 60$ & 6.39 & $5 \cdot 72$ & 5.47 & 5.59 \\
\hline Met $(\mathrm{g} / \mathrm{kg})$ & 6.59 & 6.59 & 6.58 & $6 \cdot 68$ & 6.59 & 6.61 \\
\hline Cys $(\mathrm{g} / \mathrm{kg})$ & 3.49 & 3.47 & 3.46 & 3.45 & 3.46 & 3.43 \\
\hline Met + Cys $(\mathrm{g} / \mathrm{kg})$ & 9.94 & 9.94 & 9.95 & 9.98 & 9.95 & 9.96 \\
\hline Lys $(\mathrm{g} / \mathrm{kg})$ & $12 \cdot 96$ & $12 \cdot 97$ & $12 \cdot 96$ & 12.99 & 12.95 & 12.97 \\
\hline $\operatorname{Thr}(\mathrm{g} / \mathrm{kg})$ & 0.88 & 0.88 & 0.87 & 0.89 & 0.88 & 0.87 \\
\hline $\operatorname{Arg}(\mathrm{g} / \mathrm{kg})$ & 13.65 & 13.85 & 13.67 & 13.95 & 13.74 & 13.83 \\
\hline
\end{tabular}

LME, basal diet with energy reduction below the level recommended by Ross 308 (2014) broiler manual (starter: $11.93 \mathrm{MJ} / \mathrm{kg}$ and grower: $12.33 \mathrm{MJ} / \mathrm{kg}$ ); STD, basal diet with energy level recommended by Ross 308 (2014) broiler manual (starter: $12.56 \mathrm{MJ} / \mathrm{kg}$ and grower: $12.97 \mathrm{MJ} / \mathrm{kg}$ ); GAA0, basal diet; GAA0.6, basal diet supplemented with 0.6 g/kg guanidinoacetic acid; GAA1.2, basal diet supplemented with $1.2 \mathrm{~g} / \mathrm{kg}$ guanidinoacetic acid; SBM, soyabean meal; GAA, guanidinoacetic acid.

* Vitamin premix provided per $\mathrm{kg}$ of diet: vitamin A (retinol), $3600 \mu \mathrm{g}$; vitamin $\mathrm{D}_{3}$ (cholecalciferol), $125 \mu \mathrm{g}$; vitamin $\mathrm{E}$ (tocopheryl acetate), $63 \mathrm{mg}$; vitamin $\mathrm{K}_{3}, 3.5 \mathrm{mg}$; thiamine, $3 \mathrm{mg}$; riboflavin, $7.5 \mathrm{mg}$; pantothenic acid, $18 \mathrm{mg}$; pyridoxine, $4.3 \mathrm{mg}$; cyanocobalamin, $0.017 \mathrm{mg}$; niacin, $65 \mathrm{mg}$; biotin, $0.3 \mathrm{mg}$; folic acid, $2 \mathrm{mg}$; choline chloride, $600 \mathrm{mg}$; antioxidant $100 \mathrm{mg}$; mineral premix provided per kg of diet: $\mathrm{Fe}\left(\mathrm{FeSO}_{4} \cdot 7 \mathrm{H}_{2} \mathrm{O}, 20.09 \% \mathrm{Fe}\right), 80 \mathrm{mg} ; \mathrm{Mn}\left(\mathrm{MnSO}_{4} \cdot \mathrm{H}_{2} \mathrm{O}, 32.49 \% \mathrm{Mn}\right), 120 \mathrm{mg} ; \mathrm{Zn}(\mathrm{ZnO}, 80 \cdot 35 \% \mathrm{Zn}), 110 \mathrm{mg} ; \mathrm{Cu}\left(\mathrm{CuSO} .5 \mathrm{H}_{2} \mathrm{O}\right)$, $16 \mathrm{mg}$; iodine (KI, $58 \% \mathrm{I}), 1.3 \mathrm{mg}$; $\mathrm{Se}\left(\mathrm{NaSeO}_{3}, 45.56 \% \mathrm{Se}\right), 0.3 \mathrm{mg}$.

by centrifuging the blood samples at $3000 \boldsymbol{g}$ for $20 \mathrm{~min}$ at $4{ }^{\circ} \mathrm{C}$ using a centrifuge (Pars Azma), and stored at $-20^{\circ} \mathrm{C}$ until required. We determined serum levels of total protein (TP), uric acid (UA) and creatinine using commercial kits (Pars Azmoon). All analyses were performed in duplicate.

\section{Laboratory analyses}

Before trial commencement, feed ingredients were analysed by Evonik Industries AG animal nutrition analytical laboratory for crude protein $\left(\right.$ AMINOProx $\left.^{\circledR}\right)$, amino acids (AMINONIR ${ }^{\circledR}$ ), diethyl ether extract $\left(\right.$ AMINOProx $\left.^{\circledR}\right)$, DM (AMINOLab ${ }^{\circledR}$ ) and total and phytate phosphorous (AMINOProx ${ }^{\circledR}$ ) contents. Furthermore, dietary samples were analysed for the profile of amino acids by AMINOLab ${ }^{\circledR}$. In addition, the experimental diets and the excreta were analysed for gross energy (GE) and AIA in order to determine dietary AME. The GE was determined using an adiabatic bomb calorimeter (Gallenkamp) standardised with benzoic acid. The AIA in feed and excreta was determined using the method of Vogtmann et al. ${ }^{(21)}$. The $\mathrm{N}$ contents of the feed and freeze-dried carcass samples were determined by the Kjeldahl method (984.13) ${ }^{(22)}$. The crude fat in the feed and carcass samples was extracted using soxhelt fat analysis according to the method 920.39 of Association of Official Analytical Chemists ${ }^{(22)}$.

\section{Calculations}

A series of calculations were carried out to calculate energy utilisation according to Olukosi et al. ${ }^{(23)}$ and Pirgozliev \& Bedford $^{(24)}$. Dietary AME (MJ/kg) was calculated as follows:

$$
\operatorname{AME}(\mathrm{MJ} / \mathrm{kg} \text { of diet })=\mathrm{GE}_{\mathrm{f}}-\left(\mathrm{GE}_{\mathrm{e}} \times\left(\mathrm{AIA}_{\mathrm{d}}\right) /\left(\mathrm{AIA}_{\mathrm{e}}\right)\right)
$$

where $\mathrm{GE}_{\mathrm{f}}$ is the $\mathrm{GE}(\mathrm{MJ} / \mathrm{kg})$ of the feed, $\mathrm{GE}_{\mathrm{e}}$ is the $\mathrm{GE}(\mathrm{MJ} / \mathrm{kg})$ of the excreta, $\mathrm{AIA}_{d}$ is the AIA in the diets (\%) and $\mathrm{AIA}_{\mathrm{e}}$ is the AIA in the excreta (\%). 
The total carcass GE retained in the body was calculated as the sum of the carcass $\mathrm{RE}_{\mathrm{p}}$ and $\mathrm{RE}_{\mathrm{f}}$. The total carcass protein retention $\left(\mathrm{CP}_{\mathrm{r}}, \mathrm{g} /\right.$ bird $)$ was calculated as follows:

$$
\mathrm{CP}_{\mathrm{r}}=\left(\mathrm{N}_{15}-\mathrm{N}_{1}\right) \times 6 \cdot 25,
$$

where $N_{15}$ is the $\mathrm{N}(\mathrm{g})$ in chicken carcasses at $15 \mathrm{~d}$ old, $\mathrm{N}_{1}$ is the $\mathrm{N}(\mathrm{g})$ in chicken carcasses at the beginning of the experiment at $1 \mathrm{~d}$ old and 6.25 is the coefficient used to calculate the $\mathrm{RE}_{\mathrm{p}}$ in the body.

The value of carcass $\mathrm{GE}$ retained as $\mathrm{RE}_{\mathrm{p}}$ was calculated as follows:

$$
\mathrm{RE}_{\mathrm{P}}=\mathrm{CP}_{\mathrm{r}} \times 23.6 \mathrm{MJ},
$$

where $\mathrm{CP}_{\mathrm{r}}(\mathrm{kg})$ is multiplied by $23.6 \mathrm{MJ}$, the amount of energy in $1 \mathrm{~kg}$ of protein.

The total carcass fat retention $\left(\mathrm{CF}_{\mathrm{r}}, \mathrm{g} / \mathrm{bird}\right)$ was calculated similar to $\mathrm{CP}_{\mathrm{r}}$ as follows:

$$
\mathrm{CF}_{\mathrm{r}}=\left(\mathrm{F}_{15}-\mathrm{F}_{1}\right),
$$

where $F_{15}$ is the fat $(\mathrm{g})$ in chicken carcasses at $15 \mathrm{~d}$ old; $F_{1}$ the fat (g) in chicken carcasses at the beginning of the experiment at $1 \mathrm{~d}$ old

The value of the carcass $\mathrm{RE}_{\mathrm{f}}$ was calculated as follows:

$$
\mathrm{RE}_{\mathrm{f}}=\mathrm{CF}_{\mathrm{r}} \times 39 \cdot 12 \mathrm{MJ}
$$

where $\mathrm{CF}_{\mathrm{r}}(\mathrm{kg})$ is multiplied by $39 \cdot 12 \mathrm{MJ}$, the amount of energy in $1 \mathrm{~kg}$ of fat.

Total energy retained in the carcass $\left(\mathrm{RE}_{\mathrm{c}}\right)$ was calculated as follows:

$$
\mathrm{RE}_{\mathrm{C}}(\mathrm{MJ})=\left(\mathrm{RE}_{\mathrm{p}}+\mathrm{RE}_{\mathrm{f}}\right) .
$$

$\mathrm{NE}_{\mathrm{p}}(\mathrm{MJ} / \mathrm{kg})$ was calculated using the following equation:

$$
\mathrm{NE}_{\mathrm{p}}(\mathrm{MJ} / \mathrm{kg})=\left(\mathrm{RE}_{\mathrm{c}}\right) / \mathrm{FI},
$$

where FI is the average amount of feed ( $\mathrm{kg} / \mathrm{bird})$ consumed from $1 \mathrm{~d}$ old until day 15.

The efficiency of AME used for energy retention $\left(\mathrm{Kr}_{\mathrm{e}}\right)$ was calculated as the $\mathrm{RE}_{\mathrm{C}}$ divided by AME intake.

$$
\mathrm{Kr}_{\mathrm{e}}=\mathrm{RE}_{\mathrm{C}} / \mathrm{AME} \text { intake, }
$$

where AME intake is the FI ( $\mathrm{kg} /$ bird) for the experimental period multiplied by determined metabolisable energy $(\mathrm{MJ} / \mathrm{kg})$ of the diets.

Total heat production $\left(\mathrm{HP}_{\mathrm{t}}\right)$ of birds from $1 \mathrm{~d}$ old to 15 days old consisting energy for tissue retention, maintenance and heat increment of production was calculated as follows:

$$
\mathrm{HP}_{\mathrm{t}}(\mathrm{MJ})=\mathrm{AME} \text { intake }-\mathrm{RE}_{\mathrm{c}} \text {. }
$$

Heat production per $\mathrm{kg}$ of feed intake $\left(\mathrm{HP}_{\mathrm{f}}, \mathrm{MJ} / \mathrm{kg}\right.$ feed intake) was calculated as follows:

$$
\mathrm{HP}_{\mathrm{f}}(\mathrm{MJ} / \mathrm{kg} \text { feed intake })=\left(\mathrm{HP}_{\mathrm{t}}\right) / \mathrm{FI},
$$

where $\mathrm{HP}_{\mathrm{t}}$ is the total heat production of the birds from $1 \mathrm{~d}$ old to $15 \mathrm{~d}$ old $(\mathrm{MJ})$, and $\mathrm{FI}(\mathrm{kg})$ consumed. The $\mathrm{NE}_{\mathrm{p}}: \mathrm{HP}_{\mathrm{f}}$ ratio describes the relative efficiency of the use of metabolisable energy between body energy retention and heat production, implicit that a more efficient split in energy towards production rather than heat increment is related to a higher ratio.

\section{Statistical analysis}

Data were analysed as a $2 \times 3$ factorial arrangement based on a completely randomised design using the GLM procedure of SAS 9.2 (SAS Institute Inc.) according to the following model:

$$
Y_{i j k}=\mu+A_{i}+B_{j}+A B_{i j}+e_{i j},
$$

where $\mu$ is the overall mean, $A_{i}$ is the fixed effect of dietary energy contents (STD and LME), $B_{j}$ is the fixed effects of dietary GAA supplementation $(0,0.6$ and $1.2 \mathrm{~g} / \mathrm{kg}), A B_{i j}$ is the interaction of dietary energy contents and GAA supplementation and $e_{i j}$ is the random residual error. Performance and energy utilisation data were analysed considering all birds in a cage as an experimental unit. Because of a possible influence of variation in AME intake on energy utilisation response criteria, the AME intake was used as a covariate in the analysis of energy utilisation. When a significant $F$-test was detected $(P<0 \cdot 05)$, corresponding means were separated by Tukey's test, and the interaction between treatments was analysed using an least square means test adjusted for Tukey's test. Pearson's correlation coefficient was employed using CORR procedure of SAS to determine any correlation between growth performance and energy utilisation data. Whenever the interaction effects of main factors were significant, the main effects were not further discussed. For all statistical analyses, significance was declared at $P \leq 0.05$ and trends at $P \leq 0.10$, unless otherwise stated. Specific orthogonal contrasts were used to test linear and quadratic effects of treatments.

\section{Results}

\section{Growth performance and carcass measurements}

There was a linear interaction between dietary energy contents and GAA level during 1-15, 15-35 and 1-35 days of age on DWG of broilers (Table $3 ; P<0.001$ ). In all noted periods, reduction of dietary energy from STD diet to LME significantly decreased DWG of broilers, which was ameliorated by $6 \cdot 1 \%$ after supplementing with $1.2 \mathrm{~g} / \mathrm{kg}$ dietary GAA $(P<0 \cdot 05)$. Additionally, DWG increased numerically by $5.2 \%$ when $0.6 \mathrm{~g} / \mathrm{kg}$ GAA was added to the LME diet across the entire rearing period compared with the birds fed non-supplemented STD diet $(P<0 \cdot 1)$. A linear interaction of dietary energy content $\times$ GAA was observed for FCR in growing $(P<0.014)$ and whole rearing periods $(P<0 \cdot 001)$, where the FCR impaired with consumption of LME feed, but reversed by dietary supplementation with $0.6 \mathrm{~g} / \mathrm{kg}$ or $1.2 \mathrm{~g} / \mathrm{kg}$ GAA $(P<0 \cdot 05)$. Dietary energy level interacted with GAA (quadratic; $P<0.001$ ) for the DFI during starter period so that the feed consumption was greater in broiler chickens fed STD diet supplemented with $1.2 \mathrm{~g} / \mathrm{kg}$ GAA than those fed LME diet supplemented with $0.6 \mathrm{~g} / \mathrm{kg}$ GAA $(P<0.05)$.

On day 35 of age, the abdominal fat was significantly greater in birds fed STD diet containing $1.2 \mathrm{~g} / \mathrm{kg}$ GAA than those fed LME diets without any supplemental GAA (online Supplementary Table S1; $P<0 \cdot 05)$. Other carcass traits were neither affected by experimental diets nor by age ( 15 or $35 \mathrm{~d}$ of age). 
Table 3. Effects of dietary treatments on the performance of broiler chickens at different ages

\begin{tabular}{|c|c|c|c|c|c|c|c|c|c|c|}
\hline \multirow[b]{2}{*}{ Energy levels } & \multirow[b]{2}{*}{ GAA $(\mathrm{g} / \mathrm{kg})$} & \multicolumn{3}{|c|}{ Daily weight gain (g) } & \multicolumn{3}{|c|}{ Daily feed intake (g) } & \multicolumn{3}{|c|}{ Feed conversion ratio } \\
\hline & & $1-15 d$ & $15-35 d$ & $1-35 d$ & $1-15 d$ & $15-35 d$ & $1-35 d$ & $1-15 d$ & $15-35 d$ & $1-35 d$ \\
\hline \multicolumn{11}{|l|}{ Energy level } \\
\hline STD & & $32 \cdot 6^{\mathrm{a}}$ & $85 \cdot 5^{\mathrm{a}}$ & $60 \cdot 6^{\mathrm{a}}$ & $47 \cdot 0^{\mathrm{a}}$ & $152 \cdot 2$ & 99.637 & $1.44^{\mathrm{a}}$ & $1 \cdot 87^{\mathrm{b}}$ & $1.64^{\mathrm{b}}$ \\
\hline LME & & $30 \cdot 3^{b}$ & $78 \cdot 2^{\mathrm{b}}$ & $55 \cdot 1^{\mathrm{b}}$ & $45 \cdot 5^{\mathrm{b}}$ & $150 \cdot 4$ & 97.842 & $1.48^{\mathrm{b}}$ & $2.04^{a}$ & $1.76^{\mathrm{a}}$ \\
\hline \multicolumn{11}{|l|}{ GAA ( $\mathrm{g} / \mathrm{kg})$} \\
\hline 0 & & 31.0 & 83.7 & $56 \cdot 4^{\mathrm{b}}$ & $46 \cdot 8^{\mathrm{a}}$ & 153.6 & 99.3 & 1.49 & 2.03 & 1.74 \\
\hline 0.6 & & 31.3 & $82 \cdot 0$ & $58 \cdot 1^{a, b}$ & $44 \cdot 7^{b}$ & $149 \cdot 9$ & 97.5 & 1.47 & 1.93 & 1.68 \\
\hline 1.2 & & $32 \cdot 1$ & 80.0 & $59 \cdot 1^{\mathrm{a}}$ & $47 \cdot 3^{a}$ & 150.5 & 99.3 & 1.42 & 1.90 & 1.68 \\
\hline \multirow[t]{3}{*}{ STD } & 0 & $32 \cdot 1^{\mathrm{a}}$ & $83.8^{\mathrm{a}}$ & $58 \cdot 9^{a, b}$ & $45 \cdot 6^{\mathrm{a}, \mathrm{b}, \mathrm{c}}$ & $152 \cdot 7$ & 98.5 & 1.42 & $1.82^{\mathrm{b}}$ & $1.67^{\mathrm{b}, \mathrm{c}}$ \\
\hline & 0.6 & $32 \cdot 8^{\mathrm{a}}$ & $87.1^{a}$ & $62 \cdot 1^{\mathrm{a}}$ & $46 \cdot 3^{\mathrm{a}, \mathrm{b}, \mathrm{c}}$ & 153.6 & 99.8 & 1.41 & $1.76^{\mathrm{b}}$ & $1.60^{\mathrm{C}}$ \\
\hline & 1.2 & $32 \cdot 9^{\mathrm{a}}$ & $85 \cdot 7^{\mathrm{a}}$ & $60 \cdot 8^{a}$ & $49 \cdot 2^{a}$ & $150 \cdot 3$ & $100 \cdot 5$ & 1.49 & $1.75^{\mathrm{b}}$ & $1.66^{b, c}$ \\
\hline \multirow[t]{3}{*}{ LME } & 0 & $30.0^{\mathrm{b}}$ & $76 \cdot 3^{b}$ & $53.9^{d}$ & $45 \cdot 0^{b, c}$ & 154.4 & $100 \cdot 1$ & 1.50 & $2 \cdot 02^{\mathrm{a}}$ & $1.85^{\mathrm{a}}$ \\
\hline & 0.6 & $29 \cdot 8^{\mathrm{b}}$ & $76 \cdot 8^{\mathrm{b}}$ & $54 \cdot 1^{c, d}$ & $43 \cdot 1^{\mathrm{c}}$ & $146 \cdot 2$ & $95 \cdot 2$ & 1.44 & $1.90^{\mathrm{a}, \mathrm{b}}$ & $1 \cdot 76^{\mathrm{a}, \mathrm{b}}$ \\
\hline & $1 \cdot 2$ & $31 \cdot 2^{a, b}$ & $81 \cdot 6^{a, b}$ & $57 \cdot 4^{\mathrm{b}, \mathrm{c}}$ & $45 \cdot 3,,^{a, b}$ & $150 \cdot 7$ & $98 \cdot 1$ & 1.45 & $1.84^{a, b}$ & $1.71^{\mathrm{a}, \mathrm{b}, \mathrm{c}}$ \\
\hline $\begin{array}{l}\text { Pooled SEM } \\
P \text { values }\end{array}$ & & 0.554 & 2.064 & 0.646 & 0.482 & 4.514 & 2.664 & 0.046 & 0.128 & 0.115 \\
\hline $\begin{array}{l}\text { Ealues } \\
\text { Energy level }\end{array}$ & & $P$ values & $-0 \cap 001$ & -0001 & 0.035 & 0.567 & 0.120 & 0,033 & ?ח०० & $<0.001$ \\
\hline $\begin{array}{l}\text { Energy level } \\
\text { GAA }\end{array}$ & & $\begin{array}{r}<0.001 \\
0.084\end{array}$ & $\begin{array}{r}<0.001 \\
0.067\end{array}$ & $\begin{array}{r}<0.001 \\
0.006\end{array}$ & $\begin{array}{l}0.035 \\
0.012\end{array}$ & $\begin{array}{l}0.567 \\
0.604\end{array}$ & $\begin{array}{l}0.120 \\
0.336\end{array}$ & $\begin{array}{l}0.033 \\
0.040\end{array}$ & $\begin{array}{l}0.002 \\
0.066\end{array}$ & $\begin{array}{r}<0.041 \\
0.044\end{array}$ \\
\hline \multicolumn{11}{|c|}{ Energy level $\times$ GAA } \\
\hline Linear & & $<0.001$ & $<0.001$ & $<0.001$ & 0.221 & 0.317 & 0.167 & 0.020 & 0.014 & $<0.001$ \\
\hline Quadratic & & 0.008 & 0.019 & $<0.001$ & $<0.001$ & 0.455 & 0.014 & 0.024 & 0.466 & 0.205 \\
\hline
\end{tabular}

GAA, guanidinoacetic acid; STD, basal diet with energy level recommended by Ross 308 (2014) broiler manual (starter: 12.56 MJ/kg and grower: 12.97 MJ/kg); LME, basal diet with energy reduction below the level recommended by Ross 308 (2014) broiler manual (starter: $11.93 \mathrm{MJ} / \mathrm{kg}$ and grower: $12 \cdot 33 \mathrm{MJ} / \mathrm{kg}$ ). a,b,c,d Values in the same column with unlike superscript letters were significantly different $(P<0.05)$.

\section{Metabolism of energy and dietary apparent metabolisable energy}

There were linear dietary energy content $\times$ GAA interactions for $\mathrm{CF}_{\mathrm{r}}\left(P<0.001\right.$; Table 5), $\mathrm{RE}_{\mathrm{C}}\left(P=0.0063\right.$; Table 5), $\mathrm{RE}_{\mathrm{f}}$ $\left(P<0.001\right.$; Table 4), NE $\mathrm{p}_{\mathrm{p}}(P=0.020$; Table 5$), \mathrm{HP}_{\mathrm{t}}(P=0.004$; Table 5), $\mathrm{HP}_{\mathrm{f}}\left(P=0.009\right.$; Table 5) and $\mathrm{NE}_{\mathrm{p}}: \mathrm{HP}_{\mathrm{f}}(P=0.010$; Table 4). In addition, a quadratic interaction was observed for dietary AME $(P=0.006$; Table 4$)$. Birds fed low AME diets with no supplemental or $0.6 \mathrm{~g} / \mathrm{kg}$ GAA had significantly lower $\mathrm{CF}_{\mathrm{r}}$, $\mathrm{RE}_{\mathrm{f}}$ and $\mathrm{RE}_{\mathrm{c}}$ than the chickens of other groups $(P<0.05$; Table 4). However, this trend was compensated by dietary supplementation of LME diet with $1.2 \mathrm{~g} / \mathrm{kg}$ GAA $(P<0.05$; Table 4). On the other hand, dietary inclusion of GAA in STD diets did not affect the carcass energy retention. The $\mathrm{kr}_{\mathrm{e}}$ tended to increase by $2.97 \%$ when the LME diet was supplemented with $1.2 \mathrm{~g} / \mathrm{kg} \mathrm{GAA}(P<0 \cdot 1$; Table 4$)$. The $\mathrm{NE}_{\mathrm{p}}$ content of basal LME diet decreased compared with the STD diet, but it was retrieved when the diet was supplemented with $1.2 \mathrm{~g} / \mathrm{kg}$ of GAA $(P<0.05$; Table 4$)$. Further, supplementing STD diet with $0.6 \mathrm{~g} / \mathrm{kg}$ GAA tended to enhance its $\mathrm{NE}_{\mathrm{p}}$ content by $4.4 \%$ $\left(P<0 \cdot 1\right.$; Table 4). Although $\mathrm{HP}_{\mathrm{t}}$ was not affected by the GAA supplementation in STD diets, it was remarkably increased in broilers fed LME diets supplemented with $1.2 \mathrm{~g} / \mathrm{kg}$ GAA $\left(P<0.05\right.$; Table 4). Moreover, $\mathrm{HP}_{\mathrm{f}}$ was lower in broilers fed LME diet with no supplemental GAA or with $1.2 \mathrm{~g} / \mathrm{kg}$ supplemental GAA compared with those fed STD diets $(P<0 \cdot 05$; Table 4).

\section{Morphology of small intestine}

Irrespective of GAA supplementation, reducing energy content of diet decreased villus height (quadratic; $P<0.001$; online Supplementary Table S2) and crypt depth (quadratic; $P=0.002$; online Supplementary Table S2). However, the V:C was not affected by energy content of diets (online Supplementary Table S2). The intestinal morphometric features in the duodenum were not affected by dietary treatments (online Supplementary Table S2). Moreover, energy content and GAA levels did not interact significantly for the intestinal morphometric features (online Supplementary Table S2).

\section{Correlations}

Table 5 presents the Pearson's correlations between growth performance and energy utilisation parameters in broiler chickens. There was a positive and significant correlation between DWG and dietary $\mathrm{NE}_{\mathrm{p}}$ during $1-15 \mathrm{~d}$ of age $(r 0.493 ; P=0.005)$, but during the same period DWG was not correlated to AME of diets. A negative correlation was found between FCR and $\mathrm{NE}_{\mathrm{p}}(r-0.591$; $P<0 \cdot 001)$, but not with dietary AME across the starter period.

\section{Blood parameters}

An interaction of GAA supplementation and dietary energy level influenced serum concentration of TP $(P=0.049$; Table 6), UA $(P=0.048$; Table 6$)$ and creatinine $(P=0.049$; Table 6$)$. The greatest concentration of serum TP was observed in birds fed LME diet supplemented with $1.2 \mathrm{~g} / \mathrm{kg}$ GAA, which was significantly greater than those fed STD diet without GAA supplementation $(P<0 \cdot 05)$. The serum concentration of UA was highest when broilers received the basal LME diet that was greater than the birds fed STD diets or fed STD feed supplemented with $1.2 \mathrm{~g} / \mathrm{kg}$ GAA $(P<0 \cdot 05)$. Chickens subjected to LME feed supplemented with $1.2 \mathrm{~g} / \mathrm{kg}$ GAA had the maximum concentration of serum creatinine, particularly compared with broilers fed basal STD diet $(P<0 \cdot 05)$. 
Table 4. Effects of dietary treatments on energy utilisation

\begin{tabular}{|c|c|c|c|c|c|c|c|c|c|c|c|c|}
\hline Energy levels & GAA $(\mathrm{g} / \mathrm{kg})$ & $\mathrm{CP}_{\mathrm{r}}(\mathrm{g} / \mathrm{bird})$ & $\mathrm{CF}_{\mathrm{r}}(\mathrm{g} / \mathrm{bird})$ & $\mathrm{RE}_{\mathrm{c}}(\mathrm{MJ})$ & $\mathrm{RE}_{\mathrm{p}}(\mathrm{MJ})$ & $\mathrm{RE}_{\mathrm{f}}(\mathrm{MJ})$ & $\mathrm{Kr}_{\mathrm{e}}$ & $\mathrm{NE}_{\mathrm{p}}(\mathrm{MJ} / \mathrm{kg})$ & $\mathrm{HP}_{\mathrm{t}}(\mathrm{MJ})$ & $\mathrm{HP}_{\mathrm{f}}(\mathrm{MJ} / \mathrm{kg})$ & $\mathrm{NE}_{\mathrm{p}}: \mathrm{HP}_{\mathrm{f}}$ & AME $(\mathrm{MJ} / \mathrm{kg})$ \\
\hline \multicolumn{13}{|l|}{ Energy level } \\
\hline STD & & 71.0 & $39 \cdot 6^{a}$ & $3 \cdot 20^{a}$ & 1.67 & $1.51^{a}$ & 0.361 & $4 \cdot 54^{a}$ & 6.92 & $9 \cdot 81^{a}$ & $0.470^{\mathrm{a}}$ & $13 \cdot 13^{a}$ \\
\hline LME & & $68 \cdot 4$ & $33.0^{b}$ & $2.90^{b}$ & 1.61 & $1 \cdot 29^{b}$ & 0.356 & $4 \cdot 15^{b}$ & $6 \cdot 46$ & $9 \cdot 47^{b}$ & $0.452^{b}$ & $12 \cdot 56^{\mathrm{b}}$ \\
\hline \multicolumn{13}{|l|}{ GAA ( $g / k g)$} \\
\hline 0 & & $69 \cdot 3$ & 38.0 & 3.03 & 1.63 & 1.46 & 0.358 & $4 \cdot 32$ & $6 \cdot 67^{b}$ & $9 \cdot 50^{b}$ & 0.460 & $12 \cdot 72$ \\
\hline 0.6 & & $68 \cdot 8$ & 33.5 & 2.97 & 1.62 & $1 \cdot 30$ & 0.360 & 4.42 & $6.49^{c}$ & $9.68^{b}$ & 0.463 & 12.82 \\
\hline $1 \cdot 2$ & & 70.9 & $37 \cdot 3$ & $3 \cdot 15$ & 1.67 & 1.44 & 0.357 & 4.45 & $6 \cdot 91^{a}$ & $9 \cdot 74^{a}$ & 0.461 & 13.00 \\
\hline \multirow[t]{3}{*}{ STD } & 0 & $68 \cdot 8$ & $42 \cdot 2^{a}$ & $3 \cdot 10^{a, b}$ & 1.62 & $1.60^{\mathrm{a}}$ & 0.362 & $4.53^{a}$ & $6 \cdot 70^{a, b}$ & $9 \cdot 80^{\mathrm{a}}$ & $0.471^{a, b}$ & $13 \cdot 06^{a}$ \\
\hline & 0.6 & $72 \cdot 8$ & $38 \cdot 4^{a, b}$ & $3 \cdot 28^{a}$ & $1 \cdot 71$ & $1.49^{a}$ & 0.374 & $4 \cdot 74^{a}$ & $6 \cdot 72^{a, b}$ & $9 \cdot 68^{a, b}$ & $0.490^{\mathrm{a}}$ & $13 \cdot 16^{a}$ \\
\hline & $1 \cdot 2$ & $71 \cdot 3$ & $38 \cdot 1^{a, b}$ & $3.22^{a}$ & 1.68 & $1.46^{a, b}$ & 0.347 & $4 \cdot 36^{a, b}$ & $7 \cdot 33^{a}$ & $9.97^{\mathrm{a}}$ & $0.443^{a, b}$ & $13 \cdot 18^{a}$ \\
\hline \multirow[t]{3}{*}{ LME } & 0 & $69 \cdot 9$ & $31 \cdot 7^{\mathrm{b}}$ & $2 \cdot 88^{b}$ & 1.64 & $1 \cdot 24^{b}$ & 0.359 & $4 \cdot 27^{b}$ & $6 \cdot 35^{b}$ & $9 \cdot 40^{\mathrm{b}}$ & $0.465^{a, b}$ & $12 \cdot 39^{b}$ \\
\hline & 0.6 & 64.9 & $28 \cdot 7^{\mathrm{b}}$ & $2 \cdot 65^{\mathrm{b}}$ & 1.53 & $1 \cdot 12^{b}$ & 0.343 & $4 \cdot 11^{b}$ & $6 \cdot 28^{b}$ & $9 \cdot 72^{\mathrm{a}}$ & $0.425^{b}$ & $12 \cdot 49^{\mathrm{b}}$ \\
\hline & $1 \cdot 2$ & $70 \cdot 4$ & $36 \cdot 5^{\mathrm{a}, \mathrm{b}}$ & $3.09^{a, b}$ & 1.66 & $1.42^{a, b}$ & 0.370 & $4.54^{a}$ & $6 \cdot 48^{a, b}$ & $9 \cdot 54^{b}$ & $0.478^{a, b}$ & $12 \cdot 82^{b}$ \\
\hline \multicolumn{13}{|l|}{$P$ values } \\
\hline Energy level & & 0.493 & $<.001$ & 0.014 & 0.485 & 0.005 & 0.022 & 0.046 & 0.110 & 0.040 & 0.038 & 0.042 \\
\hline GAA & & 0.838 & 0.155 & 0.875 & 0.840 & 0.292 & 0.759 & 0.773 & 0.047 & 0.010 & 0.722 & 0.187 \\
\hline \multicolumn{13}{|c|}{ Energy level $\times$ GAA } \\
\hline Linear & & 0.298 & $<.001$ & 0.006 & 0.298 & $<.001$ & 0.008 & 0.020 & 0.004 & 0.009 & 0.010 & 0.411 \\
\hline Quadratic & & 0.534 & 0.719 & 0.112 & 0.541 & 0.679 & 0.147 & 0.684 & 0.152 & 0.706 & 0.703 & 0.006 \\
\hline
\end{tabular}

GAA, guanidinoacetic acid; $C_{r}$, retained carcass protein ( $\left.g / b i r d\right) ; F_{r}$, retained carcass fat $(\mathrm{g} / \mathrm{bird}) ; \mathrm{RE}$, total carcass energy retained in a bird from 0 to $15 \mathrm{~d}$ of age; $R E_{\mathrm{p}}$, carcass gross energy retained as carcass protein; $\mathrm{RE}_{\mathrm{f}}$, carcass gross energy retained as carcass fat; $\mathrm{Kr}_{\mathrm{e}}$, efficiency of dietary apparent metabolisable energy retention; $\mathrm{NE}_{\mathrm{p}}$, net energy for production (carcass energy retained per kg feed intake); $\mathrm{HP}_{\mathrm{t}}$, total heat production from 0 to $15 \mathrm{~d}$ of age; $\mathrm{HP}_{\mathrm{f}}(\mathrm{MJ})$, heat production per kg feed intake; $\mathrm{STD}$, basal diet with energy level recommended by Ross 308 (2014) broiler manual (starter: $12.56 \mathrm{MJ} / \mathrm{kg}$ and grower: $12.97 \mathrm{MJ} / \mathrm{kg}$ ); LME, basal diet with energy reduction below the level recommended by Ross 308 (2014) broiler manual (starter: $11.93 \mathrm{MJ} / \mathrm{kg}$ and grower: $12.33 \mathrm{MJ} / \mathrm{kg}$ ).

a,b Values in the same column with unlike superscript letters were significantly different $(P<0.05)$.

Table 5. Correlations between growth performance and energy utilisation on day 15 of age

\begin{tabular}{|c|c|c|c|c|c|c|c|c|c|c|c|c|c|}
\hline Correlations & AME & AME intake & $R E_{p}$ & $\mathrm{RE}_{\mathrm{f}}$ & $\mathrm{RE}_{\mathrm{c}}$ & $\mathrm{NE}_{\mathrm{p}}$ & $\mathrm{HP}_{\mathrm{t}}$ & $H P_{f}$ & $\mathrm{NE}_{\mathrm{p}}: \mathrm{HP}_{\mathrm{f}}$ & $\mathrm{Kr}_{\mathrm{e}}$ & DWG $1-15$ & DFI 1-15 & FCR 1-15 \\
\hline AME & 1 & & & & & & & & & & & & \\
\hline \multirow[t]{2}{*}{ AME intake } & 0.702 & 1 & & & & & & & & & & & \\
\hline & $<0.001$ & & & & & & & & & & & & \\
\hline \multirow[t]{2}{*}{$R E_{p}$} & 0.137 & 0.410 & 1 & & & & & & & & & & \\
\hline & 0.468 & 0.024 & & & & & & & & & & & \\
\hline \multirow[t]{2}{*}{$\mathrm{RE}_{\mathrm{f}}$} & 0.238 & 0.268 & 0.397 & 1 & & & & & & & & & \\
\hline & 0.204 & 0.151 & 0.029 & & & & & & & & & & \\
\hline \multirow[t]{2}{*}{$\mathrm{RE}_{\mathrm{c}}$} & 0.194 & 0.394 & 0.569 & 0.827 & 1 & & & & & & & & \\
\hline & 0.301 & 0.031 & 0.001 & $<0.001$ & & & & & & & & & \\
\hline \multirow[t]{2}{*}{$\mathrm{NE}_{\mathrm{p}}$} & 0.232 & 0.037 & 0.350 & 0.791 & 0.851 & 1 & & & & & & & \\
\hline & 0.217 & 0.845 & 0.057 & $<0.001$ & $<0.001$ & & & & & & & & \\
\hline \multirow[t]{2}{*}{$\mathrm{HP}_{\mathrm{t}}$} & 0.661 & 0.904 & 0.198 & -0.088 & -0.025 & -0.352 & 1 & & & & & & \\
\hline & $<0.001$ & $<0.001$ & 0.293 & 0.643 & 0.894 & 0.056 & & & & & & & \\
\hline \multirow[t]{2}{*}{$\mathrm{HP}_{\mathrm{f}}$} & 0.207 & 0.243 & -0.278 & -0.567 & -0.611 & -0.711 & 0.526 & 1 & & & & & \\
\hline & 0.270 & 0.194 & 0.135 & 0.001 & $<0.001$ & $<0.001$ & 0.028 & & & & & & \\
\hline \multirow[t]{2}{*}{$\mathrm{NE}_{\mathrm{p}}: \mathrm{HP}_{\mathrm{t}}$} & 0.059 & -0.078 & 0.330 & 0.760 & 0.813 & 0.952 & -0.453 & -0.886 & 1 & & & & \\
\hline & 0.755 & 0.679 & 0.074 & $<0.001$ & $<0.001$ & $<0.001$ & 0.011 & $<0.001$ & & & & & \\
\hline \multirow[t]{2}{*}{$\mathrm{Kr}_{\mathrm{e}}$} & -0.327 & -0.363 & 0.231 & 0.595 & 0.684 & 0.814 & -0.722 & -0.778 & 0.860 & 1 & & & \\
\hline & 0.077 & 0.048 & 0.219 & $<0.001$ & $<0.001$ & $<0.001$ & $<0.001$ & $<0.001$ & $<0.001$ & & & & \\
\hline \multirow[t]{2}{*}{ DWG 1-15 } & 0.163 & 0.423 & 0.620 & 0.574 & 0.693 & 0.493 & 0.138 & -0.255 & 0.450 & 0.335 & 1 & & \\
\hline & 0.389 & 0.019 & $<0.001$ & $<0.001$ & $<0.001$ & 0.005 & 0.464 & 0.172 & 0.012 & 0.069 & & & \\
\hline \multirow[t]{2}{*}{ DFI 1-15 } & -0.060 & 0.666 & 0.433 & 0.120 & 0.341 & -0.199 & 0.579 & 0.113 & -0.174 & -0.173 & 0.999 & 1 & \\
\hline & 0.751 & $<0.001$ & 0.016 & 0.525 & 0.064 & 0.291 & $<0.001$ & 0.549 & 0.357 & 0.359 & $<0.001$ & & \\
\hline \multirow[t]{2}{*}{ FCR 1-15 } & -0.177 & 0.270 & -0.172 & -0.334 & -0.253 & -0.591 & 0.423 & 0.345 & -0.543 & -0.437 & 0.999 & 0.574 & 1 \\
\hline & 0.347 & 0.148 & 0.361 & 0.070 & 0.176 & $<0.001$ & 0.019 & 0.061 & 0.001 & 0.015 & $<0.001$ & $<0.001$ & \\
\hline
\end{tabular}

$A M E$, apparent metabolisable energy; $R E_{p}$, carcass gross energy retained as carcass protein; $R E_{f}$, carcass gross energy retained as carcass fat; $R E_{c}$, total carcass energy retained in a bird from 0 to $15 \mathrm{~d}$ of age; $\mathrm{NE}_{\mathrm{p}}$, net energy for production (carcass energy retained per $\mathrm{kg}$ feed intake); $\mathrm{HP}_{\mathrm{t}}$, total heat production from 0 to $15 \mathrm{~d}$ of age; $\mathrm{HP}_{\mathrm{f}}(\mathrm{MJ})$, heat production per $\mathrm{kg}$ feed intake; $\mathrm{Kr}_{\mathrm{e}}$, efficiency of dietary apparent metabolisable energy retention; DWG, daily weight gain; DFI, daily feed intake; FCR, feed conversion ratio.

\section{Discussion}

In the present experiment, diets were formulated with two different energy contents and supplemented with graded levels of GAA in order to study productive performance and energy utilisation in broiler chickens in response to GAA addition.
Dietary supplementation with $1.2 \mathrm{~g} / \mathrm{kg}$ GAA elevated the compromised growth, and improved the FCR of birds fed LME diets without GAA inclusion. Effects of GAA on the growth performance was likely owing to its key role as a creatine precursor and subsequently its ability to increase the muscular creatine and ATP stores ${ }^{(3)}$. Creatine plays the role of a carrier in the form 
Table 6. Effects of dietary treatments on the blood parameters of broiler chickens

\begin{tabular}{|c|c|c|c|c|}
\hline Energy levels & GAA (g/kg) & $\mathrm{TP}(\mathrm{g} / \mathrm{l})$ & $\mathrm{UA}(\mu \mathrm{mol} / \mathrm{l})$ & Creatinine $(\mu \mathrm{mol} / \mathrm{l})$ \\
\hline \multicolumn{5}{|l|}{ Energy level } \\
\hline STD & & $34 \cdot 6^{\mathrm{b}}$ & $308 \cdot 13^{b}$ & $12 \cdot 37$ \\
\hline LME & & $38.2^{\mathrm{a}}$ & $342.63^{a}$ & $14 \cdot 14$ \\
\hline \multicolumn{5}{|l|}{ GAA $(g / k g)$} \\
\hline 0 & & $35 \cdot 2$ & 342.03 & $13 \cdot 26^{a, b}$ \\
\hline 0.6 & & 36.9 & 314.08 & $11.49^{b}$ \\
\hline 1.2 & & $37 \cdot 2$ & $320 \cdot 02$ & $15 \cdot 02^{\mathrm{a}}$ \\
\hline \multirow[t]{3}{*}{ STD } & 0 & $32 \cdot 2^{\mathrm{b}}$ & $305 \cdot 75^{b}$ & $11.49^{b}$ \\
\hline & 0.6 & $36 \cdot 1^{\mathrm{a}, \mathrm{b}}$ & $318 \cdot 24^{a, b}$ & $12 \cdot 37^{\mathrm{a}, \mathrm{b}}$ \\
\hline & 1.2 & $35 \cdot 4^{a, b}$ & $300 \cdot 39^{b}$ & $12 \cdot 37^{\mathrm{a}, \mathrm{b}}$ \\
\hline \multirow[t]{3}{*}{ LME } & 0 & $38 \cdot 1^{\mathrm{a}, \mathrm{b}}$ & $378.91^{\mathrm{a}}$ & $15 \cdot 91^{\mathrm{a}}$ \\
\hline & 0.6 & $37 \cdot 7^{\mathrm{a}, \mathrm{b}}$ & $309 \cdot 91^{a, b}$ & $10 \cdot 60^{\mathrm{b}}$ \\
\hline & 1.2 & $38.9^{a}$ & $339.06^{a, b}$ & $16 \cdot 79^{a}$ \\
\hline Pooled SEM & & 0.90 & $10 \cdot 11$ & 0.88 \\
\hline \multicolumn{5}{|l|}{$P$ values } \\
\hline Energy level & & 0.042 & 0.038 & 0.092 \\
\hline GAA & & 0.593 & 0.483 & 0.031 \\
\hline \multicolumn{5}{|c|}{ Energy level × GAA } \\
\hline Linear & & 0.049 & 0.048 & 0.049 \\
\hline Quadratic & & 0.505 & 0.474 & 0.081 \\
\hline
\end{tabular}

GAA, guanidinoacetic acid; TP, total protein; UA, uric acid; STD, basal diet with energy level recommended by Ross 308 (2014) broiler manual (starter: $12.56 \mathrm{MJ} / \mathrm{kg}$ and grower: $12.97 \mathrm{MJ} / \mathrm{kg}$ ); LME, basal diet with energy reduction below the level recommended by Ross 308 (2014) broiler manual (starter: $11.93 \mathrm{MJ} / \mathrm{kg}$ and grower: $12.33 \mathrm{MJ} / \mathrm{kg}$ ).

a,b Values in the same column with unlike superscript letters were significantly different $(P<0.05)$

of phosphocreatine, enhancing the energy delivery to high demanding energy tissues such as muscles and heart ${ }^{(6)}$. It seems that the improving effects of GAA are more prominent in lowenergy and animal-product-free diets where the energy would be limiting for growth of broiler chickens with high-energy demands. These findings were consistent with the results of Lemme et $a l{ }^{(14)}$ who observed an improvement in growth of male and female broilers fed all vegetable diets supplemented with 0.6 or $1.2 \mathrm{~g} / \mathrm{kg}$ of GAA. Similarly, feeding turkeys with vegetable-based diets supplemented with $0.8 \mathrm{~g} / \mathrm{kg}$ GAA increased DWG across $1-63 \mathrm{~d}$ of age ${ }^{(15)}$. Moreover, there are some trials reporting the beneficial effect of GAA on FCR of broilers, whereas their DWG was not significantly affected $^{(13,16,17)}$. Data on feed consumption showed a reduction in birds fed LME diet supplemented with $0.6 \mathrm{~g} / \mathrm{kg}$ GAA during the starter period; however, this parameter did not change in birds subjected to the other levels of energy or GAA supplementation. As such, a comparative slaughter technique was used during the starter period to clarify the context of energy utilisation, particularly in the early stages of chick's life.

Results showed that energy was deposited in the carcass of birds mainly as protein than fat during the early stages of chick's life. Generally, broiler chickens proportionally gain more carcass protein than fat in their early stage of growth, which is supported by previous reports ${ }^{(24,25)}$. Improvements in energy utilisation depend upon the enhancement in nutrient and energy availability, leading to deposition of carcass energy in forms of fat and protein $^{(23)}$. Indeed, lower DWG, $\mathrm{CF}_{\mathrm{r}}, \mathrm{RE}_{\mathrm{c}}$ and abdominal fat in broilers fed LME diet could be owing to their reduced energy utilisation as the measured dietary $\mathrm{NE}_{\mathrm{p}}$ value was lower in these birds. In this regard, supplemental GAA successfully ameliorated the reduced growth and carcass energy retention of birds fed LME diet, suggesting the efficacy of this compound to improve energy utilisation in broiler chickens. Further, GAA supplementation in STD diets did not affect the body energy retention, providing the evidence that GAA works better in lowenergy diets. This is against the previous reports in which researchers failed to detect any interaction between GAA inclusion and dietary energy content on the growth of broilers ${ }^{(16,17)}$.

In the present experiment, $\mathrm{NE}_{\mathrm{p}}$ for $\mathrm{LME}$ feed containing $1.2 \mathrm{~g} / \mathrm{kg}$ GAA was greater than the same diet lacking supplemental GAA, which was in line with their estimated higher $\mathrm{HP}_{\mathrm{t}}$, $\mathrm{RE}_{\mathrm{c}}, \mathrm{Kr}_{\mathrm{e}}$ and consequently DWG. However, dietary AME was not affected in response to dietary supplementation with GAA. In this regard, we found that DWG of broilers was positively correlated to dietary $\mathrm{NE}_{\mathrm{p}}$, but not to AME. In other words, the dietary AME was not affected in response to dietary supplementation with GAA compared with $\mathrm{NE}_{\mathrm{p}}$. Beneficial effects of GAA on $\mathrm{NE}_{\mathrm{p}}$ could be attributed to increased buffering capacity for ATP by phosphocreatine hydrolysis in muscles, consistent with the idea that GAA increases muscle growth or work; therefore, chickens spent more energy towards growth rather than maintenance. In this study, we did not measure the effect of GAA on net energy for maintenance; therefore, further investigations are warranted.

The $\mathrm{HP}_{\mathrm{t}}$ decreased in chickens that received LME diets, but was elevated by dietary inclusion of $1.2 \mathrm{~g} / \mathrm{kg}$ GAA. It has been reported that a higher plane of nutrition leads to a greater heat production $^{(26)}$. Hence, lower $\mathrm{HP}_{\mathrm{t}}$ in $\mathrm{LME}$ diets was due to decreased dietary energy intake through the energy sources of dietary ingredients. Energy expenditure comprises tissue respiration and energy-dependent nutrient transportation such as Na-K ATPase ${ }^{(23)}$. Furthermore, organs such as liver, gastrointestinal tract and pancreas are involved in almost $30 \%$ of fasting heat production ${ }^{(27)}$. Experimental evidence has shown that GAA may affect the proportional weight of the liver ${ }^{(16,17)}$. Because liver weight in the current trial was not changed in response to the inclusion of GAA, it is likely that higher heat 
production in broilers given GAA was due to the increased energy expenditure associated with maintenance of skeletal muscles and fat, taking into consideration that heat production for muscle deposition is more than fat ${ }^{(28)}$. This speculation seems plausible as dietary supplementation of LME diet with $1.2 \mathrm{~g} / \mathrm{kg}$ GAA increased energy $\mathrm{RE}_{\mathrm{f}}$ and $\mathrm{RE}_{\mathrm{p}}$ in broilers' carcass.

Morphology of certain segments of small intestine was studied to evaluate whether dietary supplementation with GAA affects intestinal digestibility of nutrients. Although the impact of arginine as a precursor for GAA and creatine was evaluated previously ${ }^{(10)}$, there is a dearth of reports linking the effects of GAA in diets with reduction of energy content on the intestinal morphology. Our results indicated that gut morphometrical attributes were not changed in the birds fed GAA-added diets. Therefore, it could be postulated that GAA supplementation in the diet may have no effect on intestinal digestibility of nutrients in broiler chickens. We found that reduction in energy content of diet decreased villus height and crypt depth in the jejunum. A deeper intestinal crypt is a criterion for greater tissue turnover and the need for new tissue, which increases the demand for maintenance energy ${ }^{(29)}$. Therefore, the lower depth of crypt and height of villi when birds subjected to lower energy diets may stand to reason that epithelial cells of intestine encountered with the lack of energy required for their proliferation. Analogous to our data, Fleming et $a l^{(30)}$ found that proliferation of epithelial cells in the intestine of young male rats decreased by lowering the energy intake. Moreover, Ale Saheb Fosoul et al. ${ }^{(31)}$ reported the anatomical variations in the small intestine of broiler chicken given diets with alternating energy contents.

UA is the final and main poultry nitrogenous waste product $^{(32)}$. Reduction in serum concentration of UA in the present experiment agreed with studies in which reduction of dietary energy to protein ratio increased plasma concentration of UA in broiler chickens ${ }^{(33,34)}$. Moreover, dietary energy restriction has been shown to increase the plasma $\mathrm{UA}^{(35)}$. Indeed, any changes in protein metabolism could be reflected as altered blood concentration of $\mathrm{UA}^{(36)}$. High levels of serum UA is likely associated with utilisation of structural proteins as energy sources when animals encounter energy restriction. In the present study, serum UA decreased marginally after supplementing LME diet with GAA, supporting the idea that GAA supplementation improves protein and energy utilisation. Besides, serum concentration of TP was the greatest in chickens fed LME diet supplemented with $1.2 \mathrm{~g} / \mathrm{kg}$ GAA, which further supports the idea that GAA supplementation improves protein utilisation in broiler chickens specifically when energy is limited in their diet. Creatinine is a product of metabolic breakdown of phosphocreatinine in skeletal muscle, and its blood level is proportional to muscle mass ${ }^{(6)}$. Serum concentration of creatinine increased in response to feeding broiler chickens with LME diets with or without $1.2 \mathrm{~g} / \mathrm{kg}$ supplemental GAA. In this respect, Kubíková et al. ${ }^{(37)}$ observed an increase in plasma creatinine in response to feed restriction in broiler breeders. Moreover, muscular concentration of creatinine increased after supplementing diets with graded levels of GAA in broiler chickens ${ }^{(14)}$.

In conclusion, feeding diets supplemented with $1.2 \mathrm{~g} / \mathrm{kg}$ GAA could decrease the adverse effects of dietary energy reduction on performance of broiler chickens across different age periods specifically in early stage of growth. Such a beneficial effect of supplemental GAA cannot be attributed to improved DFI or intestinal digestibility. It seems that enhancement in buffering capacity for ATP in the muscles exerted by supplemental GAA affected the metabolism of energy in broiler chickens fed diets with energy reduction. In this respect, retained energy in carcass increased during $1-15 \mathrm{~d}$ of age owing to improved energy utilisation by GAA in LME diets. In addition, effects of dietary energy reduction and GAA inclusion was reflected in blood-related parameters. The growth performance of broilers was more sensitive to $\mathrm{NE}_{\mathrm{p}}$ of diet than to AME. Additionally, effects of GAA on $\mathrm{NE}_{\mathrm{p}}$ was more pronounced in diets with lower energy content.

\section{Acknowledgement}

Authors greatly acknowledge the Evonik Degussa representative in Iran for supplying GAA.

This research was financially supported by Lorestan University (grant no. 12236-42).

S. S. A. S. F. contributed to the project idea, design and execution of the study. A. A. was in charge of project idea and writing the manuscript. A. G. participated in project implementation and $\mathrm{H}$. K. was involved in manuscript revision.

None of the authors has any conflicts of interest to declare.

\section{Supplementary material}

For supplementary material/s referred to in this article, please visit https://doi.10.1017/S0007114517003701

\section{References}

1. Cooke BC (1987) impact of declaration of the metabolizable energy (ME) value of poultry feeds. In Recent Advances in Animal Nutrition, pp. 19-26 [W Haresing and DJA Cole, editors]. London: Butterworths, University Press.

2. Noblet J, Van Milgen J \& Dubois S (2010) Utilisation of metabolisable energy of feeds in pigs and poultry: interest of net energy systems. 21th Annual Australian Poultry Science Symposium. Sydney, NSW, pp. 26-35.

3. Lemme A, Ringel J, Sterk A, et al. (2007) Supplemental guanidino acetic acid affects energy metabolism of broilers. Proceedings of the 16th European Symposium on Poultry Nutrition. Strasbourg, pp. 335-338.

4. Ostojic SM (2017) Tackling guanidinoacetic acid for advanced cellular bioenergetics. Nutrition 34, 55-57.

5. Campbell JW (1995) Excretory nitrogen metabolism in reptiles and birds. In Nitrogen Metabolism and Excretion, pp. 147-178 [PJ Walsh and P Wright, editors]. Boca Raton, FL: CRC Press.

6. Wyss M \& Kaddurah-Daouk R (2000) Creatine and creatinine metabolism. Physiol Rev 80, 1107-1213.

7. Brosnan JT, Wijekoon EP, Warford-Woolgar L, et al. (2009) Creatine synthesis is a major metabolic process in neonatal piglets and has important implications for amino acid metabolism and methyl balance. J Nutr 139, 1292-1297.

8. Wallimann $\mathrm{T}$, Tokarska-Schlattner $\mathrm{M}$, Neumann $\mathrm{D}$, et al. (2007) The phosphocreatine circuit: molecular and cellular physiology of creatine kinases, sensitivity to free radicals, and enhancement by creatine supplementation. In Molecular 
System Bioenergetics: Energy for Life, pp. 195-264 [V Saks, editor]. Darmstadt: Wiley-VCH Verlag GmbH\&Co. KGaA, Weinheim.

9. Baker DH (2009) Advances in protein-amino acid nutrition of poultry. Amino Acids 37, 29-41.

10. Khajali F, Moghaddam MH \& Hassanpour H (2014) An L-arginine supplement improves broiler hypertensive response and gut function in broiler chickens reared at high altitude. Int J Biometeorol 58, 1175-1179.

11. Ostojic SM, Ostojic J, Drid P, et al. (2016) Guanidinoacetic acid versus creatine for improved brain and muscle creatine levels: a superiority pilot trial in healthy men. Appl Physiol Nutr Metab 41, 1005-1007.

12. McBreairty LE, Robinson JL, Furlong KR, et al. (2015) Guanidinoacetate is more effective than creatine at enhancing tissue creatine stores while consequently limiting methionine availability in Yucatan miniature pigs. PLOS ONE 10, e0131563.

13. Michiels J, Maertens L, Buyse J, et al. (2012) Supplementation of guanidinoacetic acid to broiler diets: effects on performance, carcass characteristics, meat quality, and energy metabolism. Poult Sci 91, 402-412.

14. Lemme A, Ringel J, Rostagno HS, et al. (2007) Supplemental guanidino acetic acid improved feed conversion, weight gain, and breast meat yield in male and female broilers. Proceedings of the 16th European Symposium on Poultry Nutrition. Strasbourg, pp. 339-342.

15. Lemme A, Gobbi R, Helmbrecht A, et al. (2010) Use of guanidino acetic acid in all-vegetable diets for Turkeys, Proceedings 4th Turkey Science Production Conference Macclesfield, UK. Turkeytimes, Tarporley, Cheshire, pp. 57-61.

16. Abudabos AM, Saleh F, Lemme A, et al. (2014) The relationship between guanidino acetic acid and metabolisable energy level of diets on performance of broiler chickens. Italian J Anim Sci 13, 548-556.

17. Mousavi SN, Afsar A \& Lotfollahian H (2013) Effects of guanidinoacetic acid supplementation to broiler diets with varying energy contents. J Appl Poult Res 22, 47-54.

18. Ringel J, Lemme A, Knox A, et al. (2007) Effects of graded levels of creatine and guanidino acetic acid in vegetable-based diets on performance and biochemical parameters in muscle tissue, 16th European Symposium on Poultry Nutrition. Strasbourg, pp. 387-390.

19. Tossenberger J, Rademacher M, Németh K, et al. (2016) Digestibility and metabolism of dietary guanidino acetic acid fed to broilers. Poult Sci $\mathbf{9 5}, 2058-2067$.

20. Aviagen (2014) Ross 308 Broiler. In Nutrition Specification [RB Limited, editor]. Newbridge, Midlothian, Scotland: Aviagen.

21. Vogtmann H, Pfirter HP \& Prabucki AL (1975) A new method of determining metabolisability of energy and digestibility of fatty acids in broiler diets. Br Poult Sci 16, 531-534.

22. Association of Official Analytical Chemists (1994) Official Methods of Analysis, 16th ed. Washington, DC: AOAC.
23. Olukosi OA, Cowieson AJ \& Adeola O (2008) Energy utilization and growth performance of broilers receiving diets supplemented with enzymes containing carbohydrase or phytase activity individually or in combination. Br J Nutr 99 , 682-690.

24. Pirgozliev V \& Bedford MR (2013) Energy utilisation and growth performance of chicken fed diets containing graded levels of supplementary bacterial phytase. Br J Nutr 109, 248-253.

25. Jamroz D, Wiliczkiewicz A, Wertelecki T, et al. (2005) Use of active substances of plant origin in chicken diets based on maize and locally grown cereals. Br Poult Sci 46, 485-493.

26. Johnson DE (2007) Contributions of animal nutrition research to nutritional principles: energetics. J Nutr 137, 698-701.

27. Spratt RS, McBride BW, Bayley HS, et al. (1990) Energy metabolism of broiler breeder hens. 2. Contribution of tissues to total heat production in fed and fasted hens. Poult Sci 69 , $1348-1356$.

28. Close WH (1990) The evaluation of feeds through calorimetry studies. In Feedstuffs Evaluation, pp. 21-39 [J Wiseman and DJA Cole, editors]. Cambridge: Butterworths, University Press.

29. Choct M (2009) Managing gut health through nutrition. Br Poult Sci 50, 9-15.

30. Fleming SE, Youngman LD \& Ames BN (1994) Intestinal cell proliferation is influenced by intakes of protein and energy, aflatoxin, and whole-body radiation. Nutr Cancer 22, $11-30$.

31. Ale Saheb Fosoul SS, Toghyani M, Gheisari A, et al. (2016) Performance, immunity, and physiological responses of broilers to dietary energy and protein sequential variations. Poult Sci 95, 2068-2080.

32. Harr KE (2002) Clinical chemistry of companion avian species: a review. Vet Clin Pathol 31, 140-151.

33. Rosebrough RW, McMurtry JP \& Vasilatos-Younken R (1992) In vitro lipid metabolism, growth and metabolic hormone concentrations in hyperthyroid chickens. Br J Nutr 68, 667-676.

34. Rosebrough RW, McMurtry JP \& Vasilatos-Younken R (1999) Dietary protein effects on the broiler's adaptation to triiodothyronine. Growth Dev Aging 63, 85-98.

35. Chen W, Guo YM, Huang YQ, et al. (2012) Effect of energy restriction on growth, slaughter performance, serum biochemical parameters and Lpin2/WDTC1/mRNA expression of broilers in the Later phase. J Poult Sci 49, 12-19.

36. Rajman M, Juráni M, Lamošová D, et al. (2006) The effects of feed restriction on plasma biochemistry in growing meat type chickens (Gallus gallus). Comp Biochem Physiol A Mol Integr Physiol 145, 363-371.

37. Kubíková L', Výboh P \& Koštál L' (2001) Behavioural, endocrine, and metabolic effects of food restriction in broiler breeder hens. Acta Vet Brno 70, 247-257. 